\title{
Urgency Toimprove Accountability In Church Institutionsin Indonesian
}

\author{
Ahmad K. Harahap \\ akhmadkadry@gmail.com \\ Pelita Kebenaran School of Theology
}

\begin{abstract}
The ultimate form of responsibility must fundamentally involve management and this has hardly beenapparent in the journey Indonesian church institutions in general as their operations are commonly associated with belief or faith. The author studieda large religious organization based in the city of Medan - North Sumatra that manages 14 branches with 50,000 church members as an organization that has attained management standard certification, namely the ISO 9001-2015 the Quality Management System.By meeting such high expectations the church will provide satisfaction and yield trust, and openness to ecclesiastical institutions, resulting in security, comfort and peace in worship for existing church members.It is concluded that ecclesiastical institutions should dare to determine their attitude by adopting ISO 9001-2015 standards, which have been tested and succeeded well and satisfy theBethel Church of Indonesia organization Jl. JaminGinting Km.11.5 number 6, Medan.
\end{abstract}

Keyword: toimprove, accountability, church institution

\section{Introduction}

In church institutions, accountability especially in the financial sector is considered very sensitive, given the involvement of the congregation in overall finance (offerings, donations, etc.). The ultimate form of responsibility must fundamentally involve management and this has hardly beenapparent in the journey Indonesian church institutions in general as their operations are commonly associated with belief or faith. In the course of the post-modern era where the level of intelligence, knowledge, skills is higher, it is deemednecessary to provide responsibility in all areas as tangible achievements, especially in the financial division (including in church institutions). Such matters are still uncommon among ecclesiastical institutions in Indonesia; as if church members and workers do not need to know about the financial dynamics of the church and that this was previously handled by the pastor, church board members or church administrators.In this era of transparency, the above mentioned issues must be addressed according to the times, in order to create a sense of security and comfort among the congregation members.

\section{Theoretical review}

\subsection{Management}

Etymologically, the term management comes from the Latin "manus" which means "hand". In Italian "maneggiare" means controlling, in French "management" means the art of 
carrying out and regulating. Whereas in English the term management comes from the word "to manage" which means regulating. On the other hand, Robin (2005) describes management as a process of coordinating andintegration of work activities to be adjusted efficiently and effectively with or through other people. From the various views above, it can be understood that management will be realized under the following conditions:

1. the existence of cooperation

2. joint objectives

3. division of work

4. formal relations

In addition to the above there has to be an ultimate goal of achieving a work program with monitoring and controllingcapability.Thus management is a process to realize the desire to be achieved or desired by an organization, whether in business, social, government, or religious organizations.

\subsection{Management in religious institutions}

An old story of how a man named Moses, led a nation thatentrusted to him by relying on his own ability to solve many problems he must face as a responsible leader.Then a man named Jethro after seeing the way of leadership of Moses gavelt is a suggestion that Moses share responsibility with people who become trusts to process problems that arise and make decisions (problem solving anddecision making). Based on Jethro's idea, Moses formed a team work withshare the responsibility as follows:

1. Appoint a leader responsible for 1,000 people.

2. Appoint a leader responsible for 100 people.

3. Appoint a responsible leader for 50 people.

4. To appoint a responsible leader for 10 people.

In this way, delegation of authority is formed, enabling Moses asnation leaders to see things more broadly for the greater interest of the nation (control function). Based on the story above, it can be suspected that the management science has its origins in ancient times, which later is implemented into the modern age in various forms according to the development of the era itself. Drucker (2008) and Kotler (2009) as well as other experts have written in the topics of personal management, sales management, conflict management, health management, time andterritorial management and ultimately quality management, known as ISO 9001 (International Standard Organization).

\section{Method}

\subsection{Data source}

In this case, the author studies a large religious organization based in the city of Medan North Sumatra that manages 14 branches with 50,000 church members. Realizing the existence of this religious organization has attained management standard certification, namely the ISO 9001-2015 the Quality Management System.

\subsection{Analysis and results}

Ministry to the congregation with the aim of increasing satisfaction and church trust through effective system implementation includes a process for continual system improvement 
and guaranteed conformity to applicable requirements and regulations. The ISO 9001: 2015 standard is applied in the Church of Bethel Indonesia organization J1. JaminGinting Km.11,5 No. 65 (GBI Medan Plaza) for branches and certain parts according to the organizational structure chart.The scope of the specified GBI Medan Plaza quality management system is as follows:

a. Church branches

1) Sumatera Resort Branch (House of Sacrifice)

2) Lake Toba International Hotel Branch (HDTI)

3) Medan Fair Plaza Branch

4) Selecta Branch

5) J.W. Marriott Branch

6) Hermes Branch

7) Pelita Nusantara Branch

8) Novotel Branch

9) Grand Mercure Branch

10) Cambridge Branch

11) Yang Lim Branch

12) Sun Plaza Branch

13) Caribbia Branch

14) Brayan City Branch

b. Ministry departments

1) Ministry of Christ's Body:

a) Ministry of Christ's Body (Inside and Outside the City)

b) Overseas Mission Services

2) Discipleship and Teaching:

a) Service Orientation Life Division (KOM)

b) Family Altar Division (FA)

c) Children Division

d) Junior Church Division (J.C.)

e) Youth Division

f) Indonesian Bethel Women's Division (WBI)

3) Apostolic \& Prophetic:

a) Prayer Department

- Prayer Tower

b) Music Department

c) Mission \& Evangelism Department

- Unreached People Groups (UPG)

4) Pastoral:
a) Baptism Division
b) Wedding Division
c) Counseling \& Visit Division
d) Funeral Division

5) Humanitarian Services:
a. Health Division
b) Benevolence Division
c) Social Services Division
6) Purchasing
7) Secretariat 

a) Asset Division
b) General Division
c) Personnel Division
d) Observer Team Division
e) Hospitality Division

8) I.T. \& Multimedia

9) Internal Audit

The Financial department is specifically audited by a certified public accounting agency. Therefore, it is not included in the scope of the audit of ISO 9001: 2015 (quality management system). The audit results can be seen in Table 1 below.

Table 1.ISO 9001 external audit criteria

a.Meet the ISO 9001: 2015 Standard

b.Understand and meet the needs and expectations of the parties concerned, namely:

1) All fulltime staff

2) All workforce

3) The whole church:

4) GBI Synod,

Church System consisting of:

Local government

Suppliers

Community organizations and non-governmental organizations Communities around the location of worship and the people of Medan city

Nation (Indonesia) and nations: GBI synod churches fulltime welfare, application and development of expertise and service capacity

application of expertise / talents in certain service areas and development of expertise and service capacity

spiritual growth, changes in life to the better, get blessings and become blessings

- Basic Church of Bethel Indonesia

- Rules of the Bethel Indonesia Church

- Supplement I, which consists of a copy of the decree, including the Decree of the Director General of Guidance for the Community (Christian) Protestant Department of Religion Number: 211 of 1989;

- Supplement II, which consists of a copy of a certificate about GBI membership in PGI, PGPI and PII membership and explanation

- Supplement III, which contains an explanation of GBI's vision, namely "Becoming like Jesus Christ"

- Supplement IV, which contains the GBI Confession and the Translation

- Supplement V, concerning Clergy Ethics at the Bethel Church in Indonesia

- Supplement VI, concerning the Work Procedure for Indonesian Bethel Women

- Supplement VIII, concerning the Work Procedure of the Department of Youth and Children

local government regulations on religion and worship, Government Law on Manpower

the basic rules of buying and selling, contractual cooperation agreements between the two parties

the rules of CSOs and NGOs

the welfare of the community around the location and in the city of Medan, the effect of a good influence

prosperity and peace for the nation and good influence good relationships and blessings; requirements for opening a new church 
Non GBI churches good relationships and blessings
c.Monitor and review information about these relevant parties and their relevant needs.

3.3 Benefits of ISO certification for churces

The advantages of implementing the ISO 9001: 2015 system are:

a. The needs and satisfaction of the congregation can be considered, understood and improved by implementing an effective system

b. The system can be reviewed/evaluated and repaired on an ongoing basis and there are guarantees in accordance with applicable requirements and regulations

c. There is good planning and reporting in the service process

d. The existence of a good management system and orderly administration increases service efficiency

e. Transparent in all fields and the church can be an example

f. Can plan actions to overcome risks and opportunities in service

g. Establish quality objectives and planning to achieve measurable targets, relevant to service suitability, monitored and updated

h. Services can be socialized to all congregations and related parties

i. Good documentation control prevents forgery and theft of documents and facilitates identification and retrieval. Each service part process can be designed, developed and reviewed according to the needs of the congregation (preparation of teaching materials, training, sermons, events, service schedules etc.) and can controlled according to the doctrine and needs of the church

j. Monitoring, measurement, analysis and evaluation can be carried out on the performance, application and effectiveness of the quality management system

k. Preventive actions can be taken against errors, shortcomings and weaknesses in the service process system and corrective actions towards improvement

\section{Conclusion}

Based on the situation and conditions presented above, it can be concluded that the long journey of church institutions in Indonesia has reached the finish line of the first stage and it is expected that churches take corrective action and experience a change of attitude to enter the era of transparency suiting the times and continue the journey to the next stage. The author suggests that ecclesiastical institutions should dare to determine their attitude by adopting ISO 9001-2015 standards, which have been tested and succeeded well and satisfy theBethel Church of Indonesia organization Jl. JaminGinting Km.11.5 number 6, Medan. By meeting such high expectations the church will provide satisfaction and yield trust, and openness to ecclesiastical institutions, resulting in security, comfort and peace in worship for existing church members.

\section{References}

[1] Drucker, P.(2008).The coming of the New Organization. New York: Harper \& Row.

[2] Kotler, P. (2009). Marketing Management.PenerbitErlangga.

[3] Robin.S (2005) 